\title{
The macrophyte flora and vegetation of the Paučko lake (mt. Konjuh)
}

\author{
Flora Makrofita i Vegetacije Paučkog jezera (Planina Konjuh)
}

\author{
Jasmina Kamberovićl,; Avdul Adrović', Enes Modrićz, Zorana Lukić3 Radenko Nešković ${ }^{4}$
}

\footnotetext{
The Faculty of Natural Sciences and Mathematics, University of Tuzla, Univerzitetska 4, 75 000, Tuzla, Bosnia and Herzegovina

2 Public Institution Protected Landscape "Konjuh", Grab potok, bb. 72 290, Banovići, Bosnia and Herzegovina

3 Gorice 124, 76 100, Brčko District, Bosnia and Herzegovina

4 Kozjak, 75 240, Lopare, Bosnia and Herzegovina
}

\section{ABSTRACT}

The study presents the first data on biodiversity of macrophyte flora and vegetation of Paučko Lake, which is recognized as an area of great natural, landscape and hydrological value in the Protected Landscape "Konjuh". Paučko Lake has a small surface and it's located at $711 \mathrm{~m}$ a.s.l. in the catchment area of the Drinjača River.The aquatic and marsh vegetation were studied during spring and summer in 2018 using the traditional ZürichMontpellier approach. The vegetation of Paučko Lake is comprised of aquatic and marsh associations of the classes Potamogetonetea Klika in Klika et Novák 194I and Phragmito-Magnocaricetea Klika in Klika et Novák 194I. The following aquatic and marsh plant associations were identified: Myriophyllo-Potametum Soó 1934, Scirpo-Phragmitetum australis W. Koch 1926, Thelypterido palustris-Phragmitetum australis Kuiperex van Donselaar et al. 1961, Schoenoplectetum lacustris Chouard 1924, Typhetum latipholiae Lang. 1973 and Scirpetum silvatici $\mathrm{Ht}$ et $\mathrm{H}$-ić prov. (in $\mathrm{Ht}$ et al. 1974). Rare vulnerable taxa Thelypteris palustris Schott and Menyanthes trifoliata $\mathrm{L}$. were recorded in emerged littoral communities, whose habitats are under successional changes caused by excessive macrophyte overgrowth by competitor species. Restoration measures are necessary to be taken to preserve the habitats of endangered species of the Paučko Lake.

Key words: biodiversity, flora, Konjuh, macrophytes, Paučko Lake, vegetation

\section{INTRODUCTION - Uvod}

Macrophytes play an important structuring role in shallow freshwater bodies by reducing water turbidity, competing with phytoplankton by taking up nutrients from the water, enhancing the density of surface-associated organisms, changing oxygen conditions, having a significant impact on phosphorus and nitrogen dynamics and $\mathrm{pH}$. Macrophytes have an importance for the food web interactions and environmental quality of lakes (Scheffer \& Jeppesen, 1998). Studies of the aquatic and marsh communities in Bosnia and Herzegovina have been known for the Hutovo blato Natural park (Jasprica \& Carić, 2002; Jasprica et al., 2003), Bardača (Kovačević \& Stojanović, 2008), Sava river basin floodplains (Redžić et al., 2009), Velika Tišina (Bjelčić, 1954), karstic rivers (Lasić et al., 20I4) and several mine pit lakes (Kamberović \& Barudanović, 20II; 20I2; Kamberović et al., 20I4). Shallow

Corresponding author: Jasmina Kamberović, Faculty of Science and Mathematics University of Tuzla; Univerzitetska 4, 75000 Tuzla, Bosnia and Herzegovina; e-mail address: jasmina.kamberovic@untz.ba 


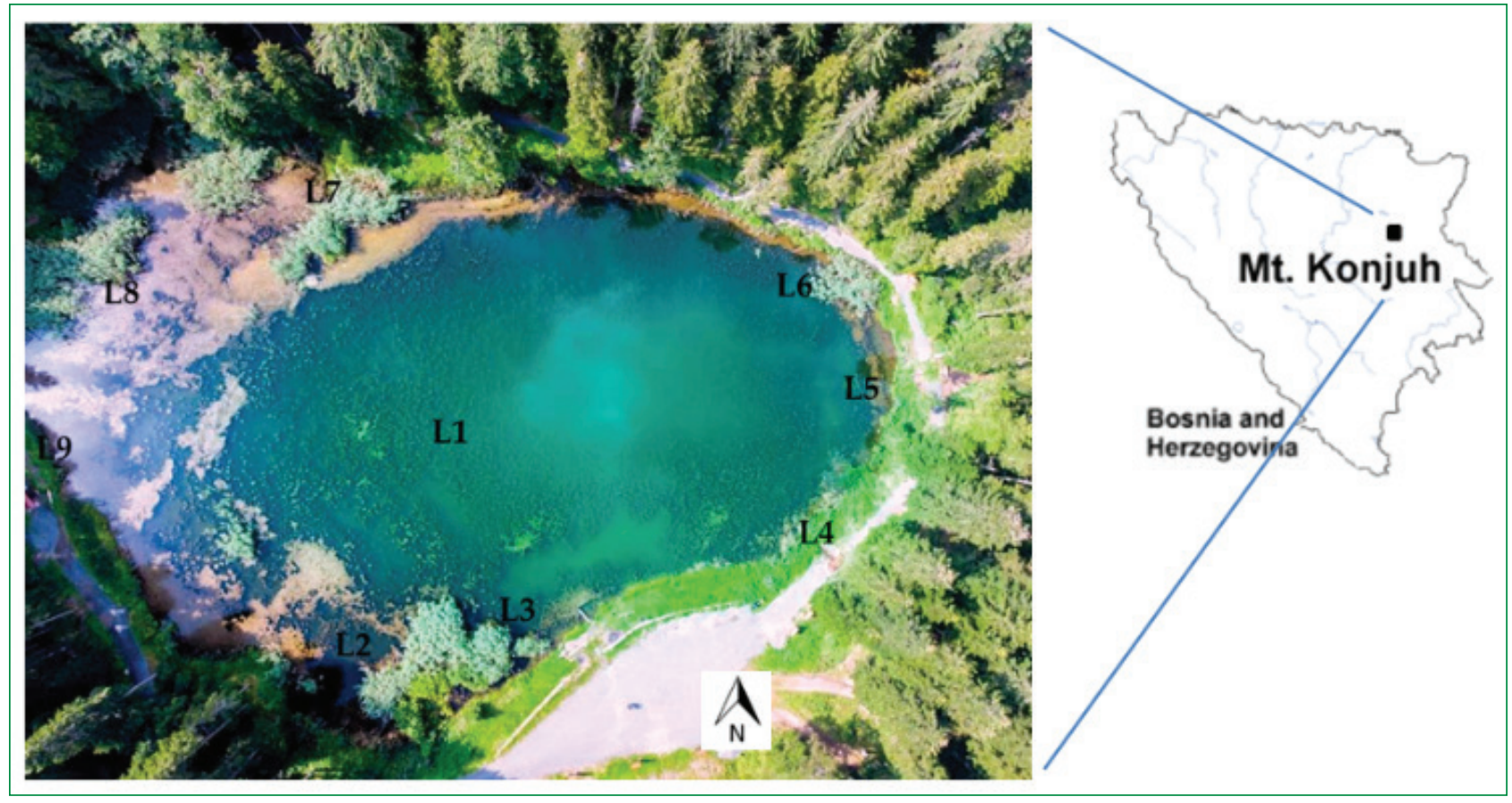

Figure I. Study area - Paučko Lake (photo by Almir Čamdžić)

Slika I. Područje istraživanja - Paučko jezero (fotografija Almir Čamdžić)

mountain lakes of Bosnia and Herzegovina are often densely overgrown with macrophytic vegetation. Paučko Lake, which is recognized as an area of natural, landscape and hydrological value of the Protected Landscape Konjuh in north-eastern Bosnia and Herzegovina (Vujatović et al. 2013) is a good example of this process. The previous research of the Paučko Lake as a wider locality site is known from the initial study on biodiversity of the Protected Landscape "Konjuh" (Public Institution Protected Landscape Konjuh, 2017), while detailed data on the floristic diversity and vegetation of this lake is missing. Previous floristic research on the Konjuh Mountain was conducted by Ritter-Studnička (1963) focusing on the vegetation on serpentines and peridotites, by Kamberović (20I5), and Kamberović et al. (20I6) focusing on algae and macrophytes in spring ecosystems. The objective of this paper is to describe floristic composition of the aquatic and marsh plant communities of the Paučko Lake, with a special emphasis on the conservation status of the plants and associations.

\section{MATERIAL AND METHODS - Materijal i metode}

\section{Methods}

Phytocenological relevés were carried out using the ZürichMontpellier approach in two vegetation seasons in 2018 (Braun-Blanquet, 1964). Determination of plants was done according to the following literature:Tutin et al. eds. (19641993), Domac (2002) and Javorka \& Csapody (1979).
The nomenclature of syntaxa follows Barudanović et al. (20I5), Mucina et al. (20I6) and Šumberová et al. (20II). Sociability of plant species and environmental factors (temperature, humidity, soil acidity, nitrification, light, continentality, and salinity) are given according to Ellenberg (Borhidi, 1993). Threatened plant species of the investigated sites are determined in accordance with Đug et al. (2013).

\section{Study area}

Paučko Lake is a small lake located at $7 \mathrm{II} \mathrm{m}$ a.s.l. in the catchment area of the Drinjača River in the Protected Landscape Konjuh, north-eastern Bosnia and Herzego-

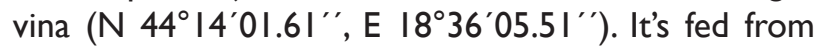
two streams and its surface is $0.44 \mathrm{~km} 2$ (Vujatović et al. 2013). The area is characterized by moderate-continental climate (Stefanović at al., 1983). Phytocoenological researches were done on nine locations, marked on the Figure I as LI-L9.

\section{RESULTS AND DISCUSSION - Rezultati i diskusija}

\section{Flora and vegetation of the Paučko Lake}

The macrophyte flora is comprised of 30 taxa in total. The dominant aquatic submerged macrophyte is the eurasian water-milfoil Myriophyllum spicatum L., which covers almost the entire bottom of the lake in the summer aspect. It is a competitive species, which forms a mono- 

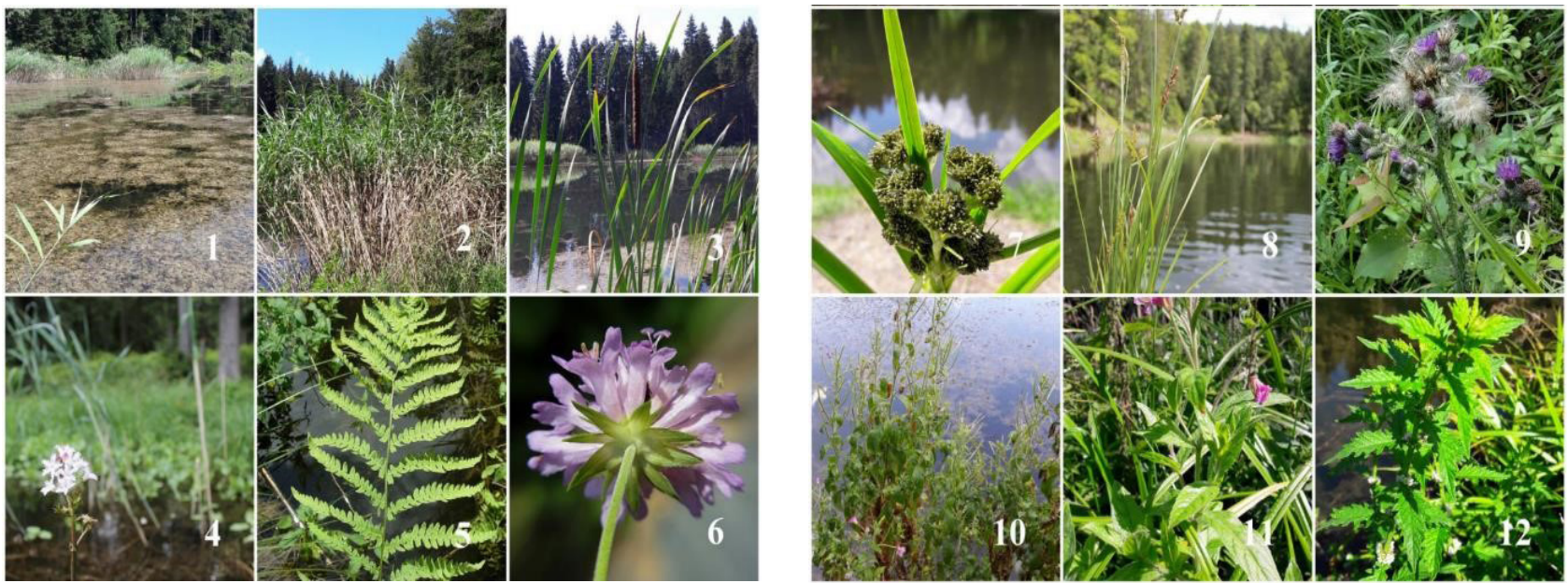

Figure 2. The common macrophyte taxa of the Paučko Lake I - Myriophyllum spicatum L., 2 - Phragmites australis (Cav.) Steud., 3 - Typha latifolia L., 4 - Menyanthes trifoliata L., 5 - Thelypteris palustris Schott, 6 - Knautia sarajevensis (Beck) Szabó.,

7 - Scirpus sylvaticus L., 8 - Carex paniculata L., 9 - Cirsium palustre (L.) Scop., 10 - Epilobium parviflorum Schreber., II Epilobium hirsutum L., 12 - Lycopus europaeus L

Slika2. Uobičajni taksoni makrofita Pučkog jezera I - Myriophyllum spicatum L., 2 - Phragmites australis (Cav.) Steud., 3 - Typha latifolia L., 4 - Menyanthes trifoliata L., 5 - Thelypteris palustris Schott, 6 - Knautia sarajevensis (Beck) Szabó., 7 - Scirpus sylvaticus L., 8 - Carex paniculata L., 9 - Cirsium palustre (L.) Scop., 10 - Epilobium parviflorum Schreber., I I - Epilobium hirsutum L., 12 - Lycopus europaeus L

dominant plant community at the Paučko Lake. Besides the above-mentioned species, very abundant were the following taxa: Typha latifolia L., Phragmites australis (Cav.) Steud, Scirpus sylvaticus L., Carex paniculata L. and Solanum dulcamara L. A total of two identified taxa are listed as threatened, Menyanthes trifoliata L. and Thelypteris palustris Schott (a vulnerable threat category). Both taxa are recorded on the southern shore of the lake. Menyanthes trifoliata has a declining population size trend in neighbouring countries Hungary, Italy and Croatia where it is classified as an endangered species (http:// www. iucnredlist.org/details/ 163993/0).According to Đug et al. (2013), this species had been recorded in Bosnia and Herzegovina in several karst fields and peats. The species Thelypteris palustris typically grows on fine substrates, peat bogs, shores of ponds and alluvial deposits along the river. It comes in a reed community at the Paučko Lake in an islet plant community.

During the investigation, we recorded only one endemic species Knautia sarajevensis (Beck) Szabó. The most common macrophyte taxa are shown on the Figure 2.

The vegetation of the Paučko Lake is comprised of six plant associations within two classes.
Class:POTAMOGETONETEA Klika in Klika et Novák 194I

Order: Potamogetonetalia Koch 1926

Alliance: Potamogetonion Libbert 1931

I.Ass. Myriophyllo-Potametum Soó 1934

Class: PHRAGMITO-MAGNOCARICETEA Klika in Klika et Novák 194I

Order: Phragmitetalia Koch 1926

Alliance: Phragmition communis Koch 1926

2.Ass. Scirpo-Phragmitetum australis W. Koch 1926

3.Ass. Typhetum latifoliae Lang. 1973

4.Ass. Schoenoplectetum lacustris Chouard 1924

Order: Magnocaricetalia Pignatti 1953

Alliance: Magnocaricion elatae Koch 1926

5. Ass. Scirpetum silvatici $\mathrm{Ht}$ et $\mathrm{H}$-ić prov. (in $\mathrm{Ht}$ et al. 1974).

Alliance: Carici-Rumicion hydrolapathi Passarge 1964 6.Ass. Thelypterido palustris-Phragmitetum australis Kuiperex van Donselaar et al. 1961

The following taxa are characteristic for vegetation classes Potamogetonetea and Phragmito-Magnocaricetea: Myriophyllum spicatum L., Phragmites australis (Cav.) Steud., Typha latifolia L., Menyanthes trifoliata L., Schoenoplectus lacustris (L.) Palla, Sparganium erectum L., Thelypteris palustris Schott, Solanum dulcamara L., Carex paniculata L., Scirpus silvaticus L., Lycopus europaeus L., Veronica beccabunga L., Epilobium hirsutum L., Epilobium parviflorum Schreber., Hypericum tetrapterum Fr., and Cirsium palustre (L.) Scop..

Species compositions of all recorded communities are summarised in the Table I. 
Table I.The phytocenological relevés of aquatic and marsh vegetation of the Paučko Lake

\begin{tabular}{|c|c|c|c|c|c|c|c|c|c|c|c|c|c|c|}
\hline Associations & & I & 2 & 2 & 3 & 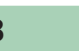 & & & 4 & & 5 & & 6 & \\
\hline Relevé & I & 2 & 3 & 4 & 5 & 6 & 7 & 8 & 9 & 10 & II & 12 & 13 & 14 \\
\hline Localities & I & I & 6 & 8 & 5 & 5 & 7 & 7 & 2 & 2 & 3 & 3 & 4 & 9 \\
\hline Date 2018 & I7.5. & |4.8. & 14.8. & |4.8. & I7.5. & 14.8. & 17.5. & 14.8. & I7.5. & 14.8. & 17.5. & 14.8. & 14.8. & 14.8. \\
\hline Water depth $(\mathrm{cm})$ & 90 & 90 & 30 & 50 & 30 & 20 & 20 & 20 & 30 & 30 & - & - & - & - \\
\hline Area of relevé $\left(\mathrm{m}^{2}\right)$ & 50 & 50 & 50 & 50 & 20 & 20 & 50 & 50 & 20 & 20 & 100 & 100 & 50 & 50 \\
\hline Density (\%) & 60 & 70 & 80 & 100 & 70 & 60 & 70 & 70 & 40 & 50 & 100 & 100 & 100 & 100 \\
\hline Taxa & & & & & & & & & & & & & & \\
\hline
\end{tabular}

Characteristic species of the ass. of the alliance

Potamogetonion

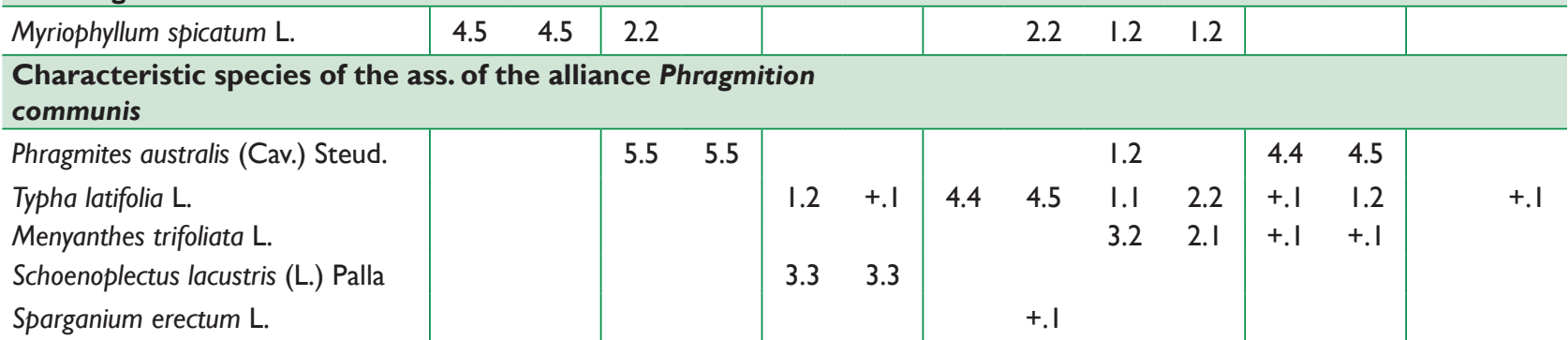

Characteristic species of the ass. of the alliance Carici-Rumicion

hydrolapathi

Thelypteris palustris Schott

Solanum dulcamara $\mathrm{L}$

\begin{tabular}{|c|c|c|c|c|c|c|c|c|c|c|}
\hline & & & & & & & & 2.3 & & \\
\hline+.1 & +.1 & 2.3 & I.I & I.I & I.I & +.1 & I.I & +.1 & +.1 & +.1 \\
\hline
\end{tabular}

Characteristic species of the ass. of the alliance Magnocarici-

on elatae

Carex paniculata $\mathrm{L}$.

\begin{tabular}{l|lr}
1.3 & $1.3+.3$
\end{tabular}

Scirpus silvaticus $\mathrm{L}$. 1.3

\begin{tabular}{lll|l|ll}
2.3 & 1.3 & 1.3 & & +.3 & +.2
\end{tabular}

Characteristic species of the ass. of the class

Phragmito-Magnocaricetea

Lycopus europaeus L.

Veronica beccabunga $\mathrm{L}$.

Epilobium hirsutum L.

Epilobium parviflorum Schreber.

Hypericum tetrapterum Fr.

Cirsium palustre (L.) Scop.

Accessory species

Athyrium filix-femina (L.) Roth.

Salix cinerea L.

Eupatorium cannabinum L.

Angelica sylvestris L.

Galeopsis speciosa Mill.

Juncus effusus $\mathrm{L}$.

Juncus inflexus $\mathrm{L}$.

Lysimachia nummularia $\mathrm{L}$.

Mentha longifolia (L.) L.

Pteridium aquilinum (L.) Kuhn

Ranunculus repens $\mathrm{L}$.

Sonchus asper (L.) Hill ssp.Asper.

Urtica dioica $\mathrm{L}$.

Knautia sarajevensis (Beck) Szabó.

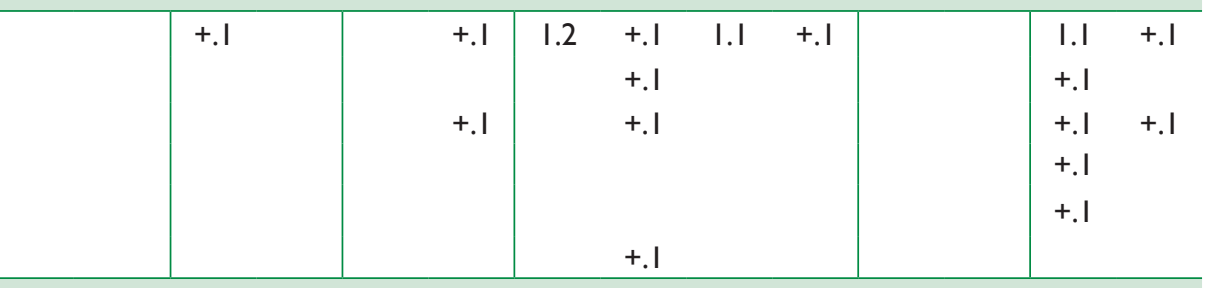

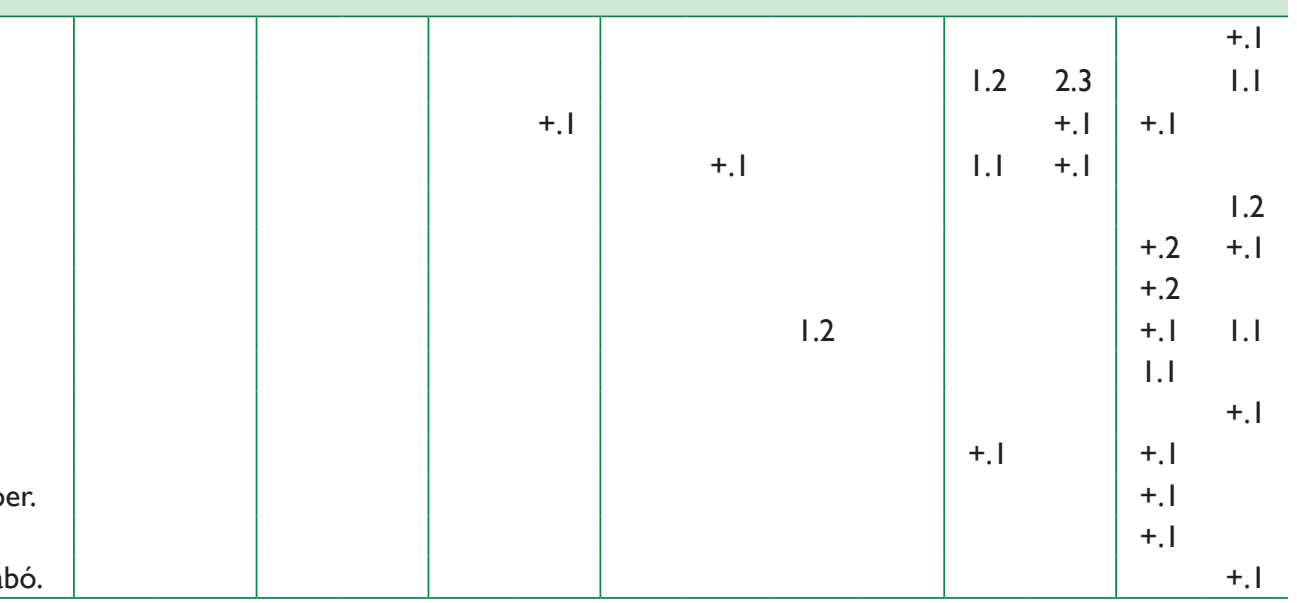

Associations:

I - Myriophyllo-Potametum Soó 1934

2 - Scirpo-Phragmitetum australis W. Koch 1926

3 - Schoenoplectetum lacustris Chouard 1924
4 - Typhetum latifoliae Lang. 1973.

5 - Thelypterido palustris-Phragmitetum australis Kuiperex van Donselaar et al. 196I

6 -Scirpetum silvatici $\mathrm{Ht}$ et $\mathrm{H}$-ić prov. (in $\mathrm{Ht}$ et al. 1974) 
Ass. Myriophyllo-Potametum Soó 1934 comprises vegetation of rooted macrophytes of mesotrophic and eutrophic freshwater bodies at low and mid-altitudes of temperate Eurasia (Mucina et al., 2016). The floristic composition of this association at Paučko Lake is made of only one species - Myriophyllum spicatum, indicating low diversity and a disturbed ecosystem function of the lake (Figure 3a). Similar to the situation on the Paučko Lake, Eurasian water milfoil took a dominant role in the colonization processes of macrophytes in pit lakes in northeastern Bosnia (Kamberović \& Barudanović, 2012).

Ass. Scirpo-Phragmitetum australis W. Koch 1926 comprises reed swamp vegetation of mesotrophic and eutrophic standing freshwater bodies of boreo-temperate Eurasia (Mucina et al., 2016). It grows on coastal areas in the northern and north-eastern shores of the lake with the water depth of $0.3-0.5 \mathrm{~m}$. The floristic composition is made of dense stands of Phragmites australis, and several less abundant taxa (Carex paniculata, Myriophyllum spicatum), or pioneer species of secondary successions (Solanum dulcamara, Lycopus europaeus). Due to the small depth of the lake, the community penetrates into the open water surface and has a high potential of causing an overgrowth of the lake (Figure 3b). In comparison with stands on Natural park Hutovo Blato (Jasprica et al., 2003 ) with 12 to 20 taxa, and those on the shores of pit lakes (Kamberović et al., 20I4), with 8 to 26 taxa, communities on the Paučko Lake are less diverse (5 taxa).

Ass. Schoenoplectetum lacustris Chouard 1924 is dominated by Schoenoplectus lacustris, a leafless species that forms sparse stands. It occurs on the eastern shore of the lake in water depths of $0.3 \mathrm{~m}$. It forms a discontinuous zone between the open water and littoral sedge vegetation. The community has poor floristic composition with only seven taxa (Figure $3 c$ ).

Ass. Typhetum latifoliae G. Lang 1973 was observed at two sites on the Paučko Lake - on the southern and northern coast, in shallow water. It's dominated by Typha latifolia. The community at the southern shore is important for conservation, as it is inhabited with vulnerable species in B\&H - Menyanthes trifoliata L. On the other hand, high overgrowing potential of cattail community on the northern shore was observed (Figure 3d).

Ass. Scirpetum silvatici $\mathrm{Ht}$ et $\mathrm{H}$-ić prov. (in $\mathrm{Ht}$ et al. 1974) is a sedge-bed marsh vegetation on oligotrophic to mesotrophic organic sediments of temperate Europe. It grows on almost the entire coastal area of the lake and relies on reed or cattail communities at the Paučko Lake. The community consists of the highest number of taxa compared to the other described communities, domi-
Ass. Thelypterido palustris-Phragmitetum australis Kuiperex van Donselaar et al. 196I belongs to the alliance Carici-Rumicion hydrolapathi Passarge 1964., or herbland vegetation on non-stabilized organic substrates in mesotrophic waters of boreal and temperate Eurasia. The association grows on an islet of 50 $\mathrm{m} 2$ on the Paučko Lake (Figure $3 \mathrm{f}$ ). It is dominated by Phragmites australis, with participation of the wetland fern. It is a rare vegetation type of mesotrophic fishponds in northern and southern Bohemia (Czech Republic) where it occurs as floating islets in 30-100 $\mathrm{cm}$ deep water. This marsh type has not been recorded earlier in Bosnia and Herzegovina, and it is valuable because of the plant species, e.g. Menyanthes trifoliata and Thelypteris palustris.

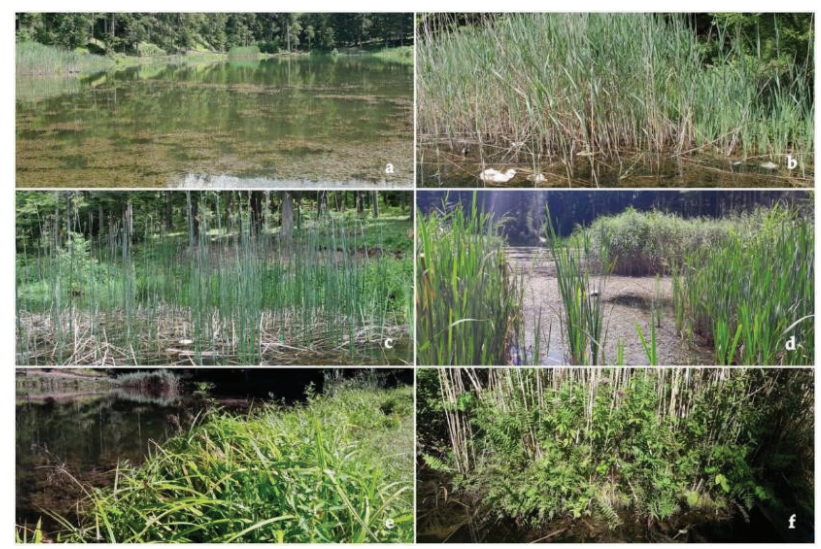

Figure 3. Identified plant associations at the Paučko Lake - a) Myriophyllo-Potametum Soó 1934, b) Scirpo-Phragmitetum australis W. Koch 1926, c) Schoenoplectetum lacustris Chouard 1924; d) Typhetum latifoliae G. Lang 1973, e) Scirpetum silvatici $\mathrm{Ht}$ et $\mathrm{H}$-ić prov. (in $\mathrm{Ht}$ et al. I 974), f) Thelypterido palustrisPhragmitetum australis Kuiperex van Donselaar et al. 1961

Slika 3. Idnetificariane biljne asocijacije Pučkog jezera a) Myriophyllo-Potametum Soó 1934, b) Scirpo-Phragmitetum australis W. Koch 1926, c) Schoenoplectetum lacustris Chouard 1924; d) Typhetum latifoliae G. Lang 1973, e) Scirpetum silvatici Ht et H-ić prov. (in $\mathrm{Ht}$ et al. 1974), f) Thelypterido palustris-Phragmitetum australis Kuiperex van Donselaar et al. 1961

\section{Ecological analysis of associations}

Ecological indexes of plant species from the analyzed communities indicate that studied communities appear on alkaline $(R=6.5-8)$, non-salinated $(S<1)$, well exposed to sunlight or shaded occasionally $(L=5.7-7.25)$, briefly flooded or submerged $(W=7.9-12)$ and mesotrophic soils $(N=5-7)$ with moderate heat requirements of their habitats $(T=5.1-5.8)$. Communities are characterized by a large proportion of sub-oceanic species which find their main areal in Central Europe ( $K=3-4)$ (Figure 4). In comparison with other studied communities, ass. Myriophyllo-Potametum has the lowest requirement for light, 
whilst ass. Schoenoplectetum lacustris has the highest requirement for nitrogen in soil. Results of ecological analysis of identified marsh communities are very similar to the research of Kamberović et al. (20l4) on marsh communities of pit lakes in north-eastern Bosnia.

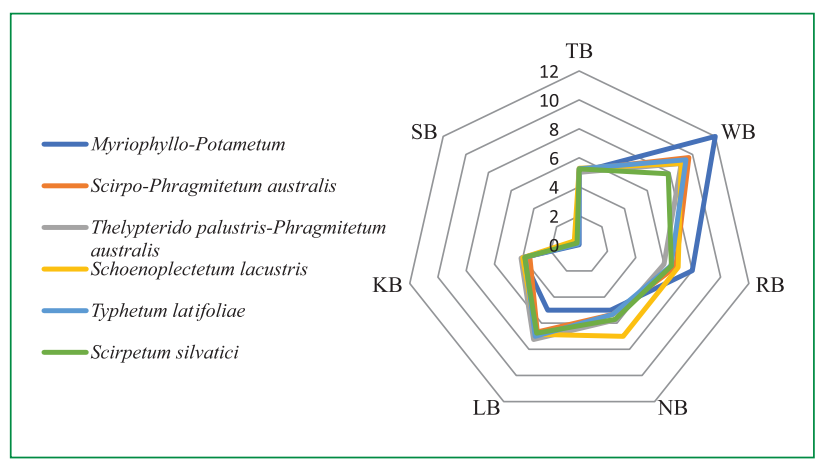

Figure 4. Ecological analysis of the studied associations ( $T$ temperature, $\mathrm{W}$ - humidity, $\mathrm{R}$ - soil acidity, $\mathrm{N}$ - nitrification, $\mathrm{L}$ - light, K - continentality, S - salinity)

Slika 4. Ekološka analiza proučavanih asocijacija ( $T$ emperatura, W - vlažnost, $R$ - kiselost tla, $N$ - nitrifikacija, L svjetlost, K - kontinentalnost, S - salinitet)

\section{Biological spectrum and sociability of plant species}

The most dominant life forms are hydrophytes and hemicriptophytes. Geophytes, chamaephytes, and especially therophytes had the lower contribution (Figure 5). Comparing the biological spectrum, the studied communities are more similar to the stands in Serbia studied by Polić (2006), and Croatia (Stančić, 20I0), than those on artificial pit lakes in north-eastern Bosnia (Kamberović et al., 2014), due to the high contribution of therophytes in pit lake marsh communities.

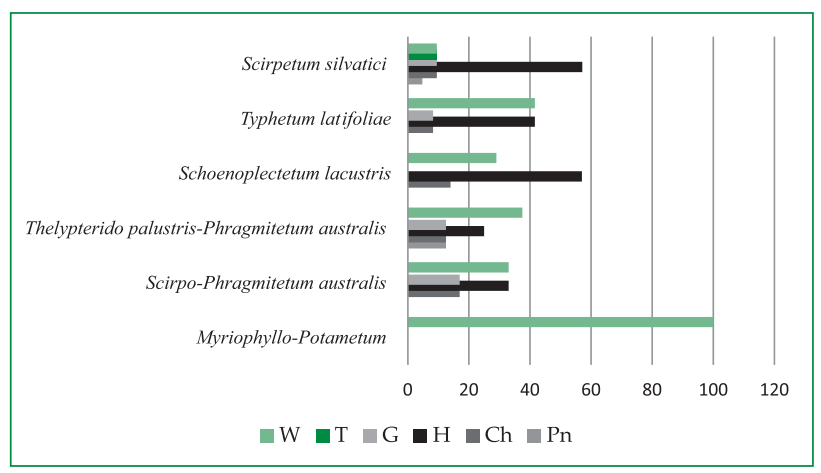

Figure 5. The biological spectrum of the studied associations: $\mathrm{W}$ - hydrophytes, $\mathrm{T}$ - therophytes, $\mathrm{G}$ - geophytes, $\mathrm{H}$ hemicriptophytes, $\mathrm{Ch}$ - chamaephytes, $\mathrm{Pn}$ - phanerophytes

Slika 5. Biološki spektar proučavanih asocijacija: W - hydrophytes, T - therophytes, G - geophytes, H hemicriptophytes, $\mathrm{Ch}$ - chamaephytes, $\mathrm{Pn}$ - phanerophytes
Analyzing the spectrum of sociability of the plant speci$\mathrm{es}$, the most frequent are competitive taxa and pioneering elements of secondary successions (Figure 6). Associated plant species had less contribution. Several taxa belong to the group of sensitive indicators (Thelypteris palustris, Menyanthes trifoliata, Veronica beccabunga). On the other hand, competitor species such as Phragmites australis, Typha latifolia and submerged Myriophyllum spicatum play an important role in the intense process of plant owergrowth of the lake.

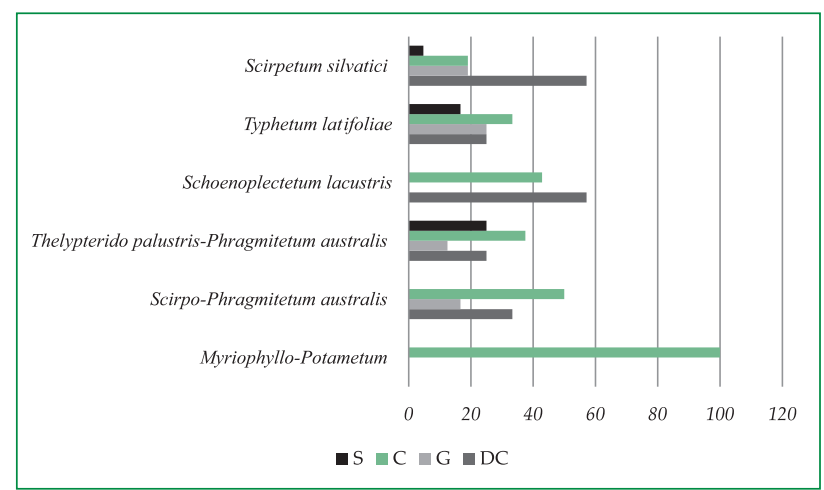

Figure 6. The social behaviour types spectrum of the studied associations $\mathrm{S}$ - sensitive species, C competitors, G - associated plant species,

DC - pioneer species of secondary successions

Slika 6. Spektar tipova društvenog ponašanja proučavanih asocijacija S - osjetljive vrste, C - konkurenti, G - pridružene

biljne vrste, DC - pionirske vrste sekundarnih sukcesija

Exploring the possibility of using helophytes as bioindicators of lake overgrowth based on long-term changes, Lawniczak-Malińska and Achtenberg (2018) concluded that lakes which currently exhibit the highest degree of overgrowth were shown to have been affected by intensive littoral growth for over 100 years. Overgrowth of helophytes on the Paučko Lake, followed by the production of submerged plants have a tendency of reducing the water surface and gradual succession of the lake into a swamp ecosystem. High productivity plants characterized by a fast growth rate, lead to the large coverage of vegetation with low taxonomic differentiation (Liira et al., 20I0). This process is observed on the $\mathrm{Pa}$ učko Lake, where the common reed, cattail and eurasian water-milfoil dominate in plant communities, and can gradually lead to the disappearance of the rare and vulnerable taxa. 


\section{CONCLUSION - Zaključak}

Paučko Lake is under high pressure caused by gradual shallowing and overgrowth by competitor species. All the while the high proportion of emerged and submerged macrophytes characterizes lake overgrowth. Six plant associations were recognized, within which a rare community Thelypterido palustris-Phragmitetum australis is observed. Rare vulnerable taxa were recorded in emerged littoral communities, whose habitats are under successional changes caused by excessive macrophyte overgrowth. Restoration measures are necessary to be taken in order to prevent the gradual disappearance of the lake.

\section{ACKNOWLEDGMENTS - Zahvala}

The paper presents the results of the research of the flora biodiversity within the project "Revitalization and protection of the Paučko Lake with the proposal of the restauration measures for its permanent protection and preservation" supported by Environmental Fund of the Federation of Bosnia and Herzegovina. The project is being implemented by the Public Institution Protected Landscape "Konjuh", realized by the Public company for water management activities Tuzla Spreča in colaboration with employees of the University of Tuzla.

\section{REFERENCES - Literatura}

Barudanović, S., \& Kamberović, J. (20I I).Weed vegetation on the shores of artificial reservoirs of surface mining pits in the area of Tuzla. Herbologia. I2 (3), I-I4.

Barudanović, S., Macanović, A., Topalić-Trivunović, Lj., \& Cero, M. (20I5). Ekosistemi Bosne i Hercegovine u funkciji održivog razvoja. Prirodno-matematički fakultet, Univerzitet u Sarajevu. Sarajevo.

Bjelčić, Ž. ( 1 954). Flora i vegetacija bare Velika Tišina kod Bosanskog Šamca. Godišnjak biološkog instituta, VII ( I/2), I8I- 207.

Borhidi,A., (1993). Social behaviour types of the Hungarian Flora, its naturalness and relative ecological indicator values. Janus Pannonius Tudom. Kiadv. Pecs.

Braun-Blanquet, J. (1964). Pflanzensociologie. 2 Aufl. In Ellenberg, H. (1986). Vegetetation Mitteleuropes mit den Alpen in okologischer Sicht. Verlag Eugen Ulmer, Stuttgart.

Domac, R. (2002). Flora Hrvatske - Priručnik za određivanje bilja, II izdanje. Zagreb: Školska knjiga.

Đug, S., Muratović, E., Drešković, N., Boškailo, A., \& Du10
2. Federalno ministarstvo okoliša i turizma.

Jasprica, N., Carić, M., \& Batistić, M. (2003). The marshland vegetation (Phragmito Magnocaricetea, IsoetoNanojuncetea) and hydrology in the Hutovo Blato natural park (Neretva river delta, Bosnia and Herzegovina). Phyton. 42 (2), 28I-294.

Jasprica, N., \& Carić, M. (2002).Vegetation of the natural park of Hutovo Blato (Neretva river delta, Bosnia and Herzegovina). Biol. Brat. (57), 505-516.

Javorka, S., \& Csapody, V. (1979). Ikonographie der Flora des Sudostlichen Metelleurope. Germany: Gustav Fisher Verlag.

Kamberović, J. (20I5). Struktura i sezonska dinamika krenonskih zajednica algi i vodenog bilja na području planine Konjuh. Doktorska disertacija. Prirodno-matematički fakultet. Univerzitet u Tuzli.

Kamberović, J., \& Barudanović, S. (20I2). Algae and macrophytes of mine pit lakes in the wider area of Tuzla, Bosnia and Herzegovina. Natura Croatica. 2I(I), I0I-I I8.

Kamberović, J., Barudanović, S., Mašić, E., \& Dedić, A. (20I4). Marshland vegetation of the order Phragmitetalia on shores of mine pit lakes in north-eastern Bosnia and Herzegovina. Biologica Nyssana. 5 (I), I-I0.

Kamberović, J., Cantonati, M., Kralj Borojević, K., Gligora Udovič, M., Žutinić, P., Hafner, D., \& Plenković-Moraj, A. (2019). Algal assemblages in springs of different lithology (ophiolithes vs. limestone) of the Konjuh Mountain (Bosnia and Herzegovina). Acta Botanica Croatica 78 (I) (accepted for publication - in press).

Kamberović, J., Kišić,A., Hafner, D., \& Plenković-Moraj,A. (2016): Comparative analysis of epilithic diatom assemblages of springs and streams in the Konjuh Mountain (Bosnia and Herzegovina). Works of the Faculty of Forestry University of Sarajevo, 2, 54 - 67.

Kovačević, Z., \& Stojanović, S. (2008). Akvatični korovi kompleksa Bardača.Acta herbologica, 17 (I), 129-I35.

Lakušić, R., Pavlović, D., Abadžić, S., \& Grgić, P. (1977). Prodromus biljnih zajednica Bosne i Hercegovine. Godišnjak Biološkog instituta Univerziteta u Sarajevu, 30.

Lasić, A., Jasprica, N., Morović, M., Kapetanović, T., Carić, M., Drešković N., Glavić, N., \& Mitić, B. (20I4). Ecological characteristics of plant species and associations along two Dinaric karstic rivers (Bosnia and Herzegovina, the Balkans). Biologia 69 (I), 40 - 52. 
Lawniczak-Malińska, E. A., \& Achtenberg, K. (2018). IndicatorValues of Emergent Vegetation in Overgrowing Lakes in Relation to Water and Sediment Chemistry. Water, I0. doi: I0.3390/w 0040498.

Liira, J., Feldmann, T., Mäemets, H., \& Peterson, U. (20I0). Two decades of macrophyte expansion on the shores of a large shallow northern temperate lake - A retrospective series of satellite images. Aquat. Bot. 93, 207-2I 5.

Mucina, L., Bültmann, H., Dierßen, K., Theurillat, J.P., Raus, T., Čarni,A., Šumberová, K.,Willner,W., Dengler,J., García, R.G., Chytrý, M., Hájek, M., Di Pietro, R., lakushenko, D., Pallas, J., Daniëls, F..A., Bergmeier, E., Santos Guerra,A., Ermakov, N., Valachovič, M., Schaminée, J.H.J., Lysenko, T., Didukh, Y.P., Pignatti, S., Rodwell, J.S., Capelo, J., Weber, H.E., Solomeshch, A., Dimopoulos, P., Aguiar, C., Hennekens, S.M., \& Tichý, L. (2016). Vegetation of Europe: hierarchical floristic classification system of vascular plant, bryophyte, lichen, and algal communities.Appl.Veg. Sci. 19, 3 - 264.

Polić, D. (2006). Florističko-fitocenološko proučavanje Labudovog okna. Biblioteka Academia. Beograd: Zadužbina Adrejević.

Public Institution Protected Landscape Konjuh, (2017): Izvještaj o polaznoj osnovi stanja biodiverziteta Zaštićenog pejzaža "Konjuh". Javna ustanova Zaštićeni pejzaž "Konjuh". Konsultant "ENOVA" d.o.o. Sarajevo.

Redžić, S., Barudanović, S., Trakić, S., Kulijer, D., Plavac, I., Posavec-Vukelić, V., Rodić-Baranović, P., Topić, R., Stojšić, V., Perić, R., Lazarević, P., Kiš, A., Stojanović,V., \& Kitnaes, S. (2009). Habitat Interpretation Sheets Natura 2000 habitat types occurring along the Sava River. Protection of biodiversity of the Sava River basin floodplains. Project Results (CD) funded by LIFE III, Swiss SDC, Dutch $\mathrm{BBI} /$ Matra and the project partners, IUCN, I-I 29.
Ritter-Studnička H. (1963). Biljni pokrov na serpentinima u Bosni. Godišnjak Biološkog instituta Univerziteta u Sarajevu I6(I-2), 9|-I99.

Scheffer, M., \& Jeppesen, E. (1998).Alternative Stable States. In: Jeppesen, E., Søndergaard, M., Søndergaard M., \& Christoffersen K. (eds): The Structuring Role of Submerged Macrophytes in Lakes. Ecological Studies (Analysis and Synthesis), I 31 . Springer, New York.

Stančić, Z. (2010). Marshland vegetation of the class Phragmito-Magnocaricetea in northwest Croatia (Krapina river valley). Biologia 65/I, 39-53.

Stefanović,V., Beus V., Burlica, Č., Dizdarević, H., \& Vukorep, I. (1983). Ekološko-vegetacijska rejonizacija Bosne i Hercegovine. Šumarski fakultet u Sarajevu. Posebna izdanja, 17.

Šumberová, K., Hájková, P., Chytrý, M., Hroudová, Z., Sádlo, J., Hájek, M., Hrivnák, R., Navrátilová, J., Hanáková, P., Ekrt, L., \& Ekrtová, E. (20II). Vegetace rákosin a vysokých ostř́ic (Phragmito-Magno-Caricetea) Marsh vegetation. In Chytrý, M. ed.Vegetace České republiky 3. Vodní a mokřadní vegetace. Academia Praha, 385-579.

Tutin, T. G., Heywood,V. H., Burges, N.A., Valentine D. H., Walters, S.M. \& Webb, D.A. /ed./ (I964-1993). Flora Europaea I-5. Cambridge: Cambridge University Press.

Vujatović M. (ed.) 20I3. Prostorni plan područja posebnih obilježja Zaštićeni pejzaž "Konjuh" za period 20102030. godine. "Projekt” a.d. Banja Luka.

http://www.iucnredlist.org/details/ 163993/0.

\section{SAŽETAK}

Studija predstavlja prve podatke o biodiverzitetu makrofitne flore i vegetacije jezera Paučko, koje je u zaštićenom pejzažu "Konjuh" prepoznato kao područje velike prirodne, pejzažne i hidrološke vrijednosti. Paučko jezero ima malu površinu i nalazi se na 711 m nadmorske visine, u slivu rijeke Drinjače.Vodena i močvarna vegetacija proučavana je tokom proljeća i ljeta 2018. godine koristeći tradicionalni Zürich-Montpellier pristup. Vegetaciju Paučkog jezera čine vodene i močvarne asocijacije klasa Potamogetonetea Klika u Kliki et Novák 194I. i Phragmito-Magnocaricetea Klika u Kliki et Novák 194I. Identifikovane su sljedeće asocijacije vodenih i močvarnih biljaka: Myriophyllo-Potametum Soó 1934, Scirpo - Phragmitetum australis W. Koch 1926, Thelypterido palustris-Phragmitetum australis Kuiperex van Donselaar et al. 196I, Schoenoplectetum lacustris Chouard 1924, Typhetum latipholiae Lang. 1973. i Scirpetum silvatici Ht i H-ić prov. (u Ht i dr. 1974). Rijetki osjetljivi taksoni Thelypteris palustris Schott i Menyanthes trifoliata L. zabilježeni su u priobalnim zajednicama u nastajanju, čija su staništa pod sukcesivnim promjenama uzrokovanim prekomjernim prerastanjem makrofita od konkurentskih vrsta. Potrebne su mjere restauracije kako bi se očuvala staništa ugroženih vrsta jezera Paučko. 